\title{
Think Local-Act Local: Is It Time to Slow Down the Accelerated Move to Global Marketing?
}

\author{
Isabelle Schuiling*
}

\begin{abstract}
In view of the accelerated move of great corporations towards global marketing, the strategic changes of such companies raise interesting questions. Is marketing globalization reaching its limits after years of implementation? Is it time for companies to rethink their strategies and move back, like Coca-Cola, to a multidomestic marketing approach?
\end{abstract}

Keywords: Global Marketing; Multi-Domestic Marketing Approach; Brand Equity; Drawbacks of Marketing Globalization; Coca-Cola

Just over a year ago (March 2000) Douglas Daft, CEO of Coca-Cola, announced that the next big evolutionary step for the company would be 'going local'. CocaCola, he had concluded, was operating as a big, slow and sometimes insensitive 'global' company at a time when the market was demanding 'greater flexibility, responsiveness and local sensitivity'. In view of the accelerated move of most international firms towards global marketing, the strategic change of a company with such an undisputed 'global' brand raises interesting questions. Is marketing globalisation reaching its limits after years of implementation? Is it time for companies to rethink their strategies and move back, like Coca-Cola, to a multidomestic marketing approach?

\section{The Marketing Globalisation Debate}

The marketing globalisation debate has been exercising the minds of academics and practitioners for more than 30 years. In the 1980s, proponents like Ted Levitt have argued that movement towards standardisation was inescapable due to the fast diffusion of technologies, standardisation of consumer needs and economies of scale. Opponents like Wharton Professor Jerry Wind suggested that differences

* Lecturer in Marketing, IAG, Université Catholique de Louvain (isabelle.schuiling@uclouvain.be)

Edited by: ISTEI - University of Milan-Bicocca

ISSN: $1593-0319$

Schuiling Isabelle, Think Local-Act Local: Is It Time to Slow Down the Accelerated Move to Global Marketing?, Symphonya. Emerging Issues in Management (symphonya.unimib.it), n. 1, 2000-2001, pp. 83-87 
would remain and that it was still necessary to adapt product strategies to local markets.

In the 1990s, however, experts no longer questioned the validity of going global. They focused instead on identifying the degree of globalisation firms should achieve and for which type of product categories. The slogans 'think global, act global' or 'think global, act local' were seen everywhere in the international press and in academic journals.

Few industries have ignored the trend. Industrial companies like Caterpillar were first to leverage the advantages of global marketing. Consumer goods firms such as Mars or Procter \& Gamble followed suit while in the service industry, British Airways and Saatchi and Saatchi have been strong advocates.

\section{Reasons for the Global Marketing Acceleration}

The multi-domestic marketing approach used ten years ago by international firms such as Unilever, Nestle and Benckiser-offering products and marketing campaigns adapted to local markets-is now considered by most to be an outdated model.

The acceleration towards global marketing-standardising the maximum number of marketing elements in order to offer 'ideally' one global product, under a single global brand name and with one global positioning-can be explained in a number of ways. The approach is viewed by many firms, for example, as a powerful way to achieve new competitive advantages, notably the cost advantage generated by leveraging scale. Substantial economies can be generated in manufacturing, logistics, buying and marketing.

Then there is industry pressure. When one firm starts to globalise its marketing strategy, competitors are bound to follow suit in order not to be at a cost disadvantage.

$\square$ Procter \& Gamble, for example, started to push globalisation as a key competitive weapon in the 1990 s restructuring its marketing operations several times, streamlining its portfolio to focus on big international brands, and ultimately influencing Unilever to abandon its traditional multi-domestic approach. At the end of 1999, Unilever announced it would eliminate more than 1200 brands concentrating on just 400 leading ones and favouring those with a worldwide reach.

$\square$ Even Nestle, another past proponent of the multi-domestic approach, has announced that it will focus on six strategic brands that have global presence (Nestle, Nescafe, Buitoni, Nestea, Friskies and Maggi).

Finally, the impact of the financial community cannot be discounted. Shareholders and financial analysts favour restructuring that reduces a firm's costs and boosts the bottom line, as illustrated by the stock market's response to Unilever's announcement.

So in view of all this how come that a firm like Coca-Cola is turning back on the globalisation model and favouring the 'old' multi-domestic marketing approach? 


\section{Drawbacks of Marketing Globalisation}

Despite the huge financial advantages that it generates global marketing is a process driven mainly by supply considerations rather than market ones. It is true that other advantages such as lower prices, speed to market, standardised brand image and better control of marketing strategies can be achieved thanks to standardisation-but most of the time financial advantage is the main driver.

The problem is that the market (i.e. the consumer) is not necessarily asking for global products. Consumer needs may be converging more and more for certain segments of the population-e.g. the youth segment in Europe and indeed the worldbut that is not why firms have been going global in marketing.

The Coca-Cola example demonstrates that these drawbacks should not be underestimated when a company decides to push further towards a globalisation strategy. They can be identified as follows:

Heavy centralisation Marketing globalisation requires centralising most of the marketing operations in regional or global headquarters. Many new global or European management positions have been created centrally to develop brand strategies. The key benefit of this is to accelerate the time to market for worldwide product initiatives but it slows down the development of other marketing activities such as advertising campaigns or reactions to local competitors. Coca-Cola identified this as a key issue and it explains why the company has eliminated many jobs not only at its Atlanta headquarters but also in regional operations.

Insensitivity to local markets Global or European marketing managers at corporate headquarters, who are responsible for developing brand strategies, become less and less familiar with the reactions and needs of local consumers. Physically distant from local markets, they spend too much time on planes and in meetings and not enough in stores or with consumers.

With fewer local managers those left on the job also have to execute strategies developed by the headquarters. They have less time and fewer resources to understand consumers and formulate consumer knowledge.

For this reason Coca-Cola has given back responsibility to local teams and wants local managers to be close to consumers. Local management will be allowed to develop local advertising and even to launch local brands if they identify the need for it.

Poor local execution Despite the fact that strategies are designed centrally, the success of initiatives can vary considerably from market to market under a globalisation approach. This can be explained by the quality of local execution. The latter can be influenced by the motivation of the local teams to execute well the programmes developed centrally. It is not rare to meet demotivated local managers and where this is the case the risk is that business opportunities are lost.

No adequate products Marketing globalisation requires the development of products that satisfy the largest number of people. This often leads to products based on the lowest common denominator to please the largest possible segment of the population. Compromise on product quality can be the result.

Damaged brand equity Standardising brands leads many companies to standardise their brand positioning as well as their products. Many firms try to standardise the positioning of brands belonging to the same category but sold under different positioning in different countries. This can be done to the detriment of brand heritage and therefore brand equity. 
$\square$ The example of the dishwashing liquid business of $P \& G$ in Europe is salutary. In Belgium and the UK, both brands were profitable market leaders. Each had a different name, Fairy in UK and Dreft in Belgium. They were positioned to offer different benefits, going from mildness to hand to heavy grease cutting. The UK advertising was highly traditional, portraying a mother and child relationship, while a modern and humourous approach was used in Belgium. The decision was taken, however, to standardise these brands despite the different brand benefits, brand characters and brand images with the result that the UK advertising messages were used in Belgium. Such changes run the risk of damaging long-term brand equity.

Weakened brand image-the country of origin effect in relation to brands has been researched by academics for many years and has confirmed the impact on brand image.

The case of McDonalds, another successful global brand exampleis instructive. In May 2000 the company declared that it should not be seen as an American brand and that it wants now to follow a multilocal marketing approach. It claims that its values-cleanliness, service and price-have to be shared by all franchisees throughout the world but that the local dimension should be as strong as possible. As indicated by the Belgian Marketing Director: 'We buy locally, some of our products are typically local and restaurants are adapted to the local habits'. In Belgium, as elsewhere, a local advertising campaign has been developed.

\section{Companies Which Are Changing}

Other firms are successfully demonstrating that they can gain a competitive edge by being closer to local consumers. This does not mean that they are not trying to streamline their operations but they are not doing so at the expense of the consumer. Significantly, some have chosen to manage the business differently despite the existence in their industry of strong competitors following a more global marketing approach.

$\square$ Electrolux, the Swedish company, is number one in home appliances worldwide. It controls 25 per cent of the global market and 20 per cent in the United States as well as having good margins and strong profitability. By contrast with its key competitor Whirlpool which has developed a strong global marketing approach, Electrolux has achieved leadership with a wide range of local brands-there are 50 worldwide including Frigidaire, Zanussi, Arthur Martin and AEG-and marketing targeted to the needs and habits of local markets. Economies of scale have been achieved by centralising the buying function and streamlining the manufacturing operations. One single plant, for example, is delivering to most European countries but some local plants are kept to fulfil specific local needs. 
$\square$ In the beer market, the Belgian brewer-Interbrew-is now number two in the world, just behind the leader Anheuser Bush but in front of Heineken. Five years ago, Interbrew was not in the top 10 but is now the most profitable brewer worldwide. The company has achieved success through the acquisition of strong local brands and now has 180 of them including Canada's Labatt, the UK's Whitbread and Belgium's Stella Artois.

These examples are not intended to prove that the multi-domestic is better than the global marketing approach. They only show that there are different ways for an international firm to succeed today in the business, even alongside 'global' competitors.

\section{Is it Time to Rethink Marketing Strategies?}

As explained in this article there are unquestioned benefits in global marketing such as economies of scale, cost reduction and speed to market. But in some cases the advantages of the traditional multi-domestic approach are being sacrificed. Global marketing can lead after several years to heavy centralisation, insensitivity to local markets, poor local execution, no adequate products or damaged brand equity or image.

Companies like Coca-Cola, Electrolux or Interbrew, however, are sensibly adopting new ways of managing their businesses. They believe that the needs of local consumers are important and they are developing a localised approach to satisfy these needs.

Companies need to evaluate more carefully the essentially financial benefits of global marketing and ask if they are good for the long-term development of their business. Perhaps they should return to the basis of good marketing: the ability to develop products that best fulfil consumer needs. 